\title{
Social and Economic Aspects of Water Use in Specialty Crop Production in the USA: A Review
}

\author{
John C. Majsztrik ${ }^{1, *\left(\mathbb{D}, \text { Bridget Behe }^{2} \mathbb{D} \text {, Charles R. Hall }\right.}{ }^{3}$, Dewayne L. Ingram ${ }^{4}$, \\ Alexa J. Lamm ${ }^{5}$ D, Laura A. Warner ${ }^{6}$ and Sarah A. White ${ }^{1, * \mathbb{D}}$ \\ 1 Department of Plant and Environmental Sciences, Clemson University, E-143 Poole Agricultural Center, \\ Clemson, SC 29634-0310, USA \\ 2 Department of Horticulture, Plant and Soil Science Building, Michigan State University, East Lansing, \\ MI 48824, USA; behe@msu.edu \\ 3 Department of Horticultural Sciences, Texas A\&M University, 2133 TAMU, College Station, \\ TX, 77843-2133, USA; charliehall@tamu.edu \\ 4 Department of Horticulture, University of Kentucky, N-308F Agri. Science Center, Lexington, \\ KY 40546-0091, USA; dingram@email.uky.edu \\ 5 Department of Agricultural Leadership, Education and Communication, University of Georgia, 132 Four \\ Towers, Athens, GA 30602, USA; alamm@uga.edu \\ 6 Department of Agricultural Education and Communication, University of Florida, PO Box 112060, \\ Gainesville, FL 32611-2060, USA; lsanagorski@ufl.edu \\ * Correspondence: jmajszt@clemson.edu (J.C.M.); swhite4@clemson.edu (S.A.W.)
}

Received: 27 September 2019; Accepted: 5 November 2019; Published: 8 November 2019

\begin{abstract}
Understanding human behavior is a complicated and complex endeavor. Academicians and practitioners need to understand the underlying beliefs and motivations to identify current trends and to effectively develop means of communication and education that encourage change in attitudes and behavior. Sociological research can provide information about how and why people make decisions; this information impacts the research and extension community, helping them formulate programs and present information in a way that increases adoption rates. Life cycle assessment can document how plant production impacts the environment. Production of ornamental plants (greenhouse, container, and field produced flowers trees and shrubs) accounted for $4.4 \%$ of the total annual on-farm income and $8.8 \%$ of the crop income produced in the United States in 2017, representing a substantial portion of farmgate receipts. Greenhouse and nursery growing operations can use this information to increase production and water application efficiency and decrease input costs. Information related to the environmental impacts of plant production, derived from life cycle assessment, can also inform consumer purchase decisions. Information from water footprint analysis quantifies the relative abundance and availability of water on a regional basis, helping growers understand water dynamics in their operation and informing consumer plant purchases based on water availability and conservation preference. Economics can motivate growers to adopt new practices based on whether they are saving or making money, and consumers modify product selection based on preference for how products are produced. Specialty crop producers, including nursery and greenhouse container operations, rely heavily on high quality water from surface and groundwater resources for crop production; but irrigation return flow from these operations can contribute to impairment of water resources. This review focuses on multiple facets of the socioeconomics of water use, reuse, and irrigation return flow management in nursery and greenhouse operations, focusing on grower and consumer perceptions of water; barriers to adoption of technology and innovations by growers; economic considerations for implementing new technologies; and understanding environmental constraints through life cycle assessment and water footprint analyses. Specialty crop producers can either voluntarily adapt practices gradually to benefit both economic and environmental sustainability or they may eventually be forced to change due to external factors (e.g., regulations). Producers need to have the most current information available to inform their decisions regarding water management.
\end{abstract}


Keywords: carbon footprint; life cycle assessment (LCA); water footprint; consumer preference; specialty crop; greenhouse; nursery; sociology

\section{Introduction}

In the developing world, water is typically considered available and abundant, until there is a drought or another form of water crisis [1,2]. The reality is that water is at the center of our survival and that access to it is by no means guaranteed. Irrigated agriculture accounts for twenty-five percent of the water used worldwide, and is the largest consumer of fresh water in the world [3]. While governments and individuals strive to maintain the availability of quality water resources, many factors can change the landscape of water availability including drought, climate change, saltwater intrusion, aquifer depletion, public perceptions, and changes in government policy. For example, the Canary Islands have been experiencing water scarcity not because of physical or natural limitations, but because social and behavioral patterns are limiting access to fresh water resources for all [4]. Changing societal perceptions, behaviors, and norms are not easy, but change can be accomplished over time.

Availability of groundwater resources can significantly impact human well-being. By 2050 it is estimated that almost $20 \%$ of the world's population ( 2.14 of 10.7 billion people) will be impacted by groundwater scarcity $[5,6]$. When water scarcity becomes either an acute or chronic problem, it is likely that direct human use will maintain priority while agricultural (both row crop and specialty crop), industry, and other uses will become secondary priorities [7]. Specialty crop plant production, specifically nursery and greenhouse crops, is likely to be at the top of the list of industries whose water use is evaluated by the government and general public in terms of limiting the quality and quantity of freshwater resources allocated. To remain in business, these industries will likely have to adapt water use to lower quality sources, reduced water quantity, or both. Yet these reductions are not without cost. Reducing the number or types of ornamental plants in urban and suburban areas can have a detrimental effect on human health and wellbeing in urban and suburban communities, particularly considering increasing populations will increase population densities in urban and suburban areas [8]. Reducing the presence of plants in urban spaces had a negative effect on many aspects of human health including increased stress, reduced workplace productivity, and sick leave [9-11]. Specialty crop plant producers, particularly greenhouse and nursery container operations, are often heavily reliant on surface and groundwater resources for producing plants.

In this review, we focus on the socioeconomic facets of water use, reuse and irrigation return flow management in specialty crop production including (1) consumer and grower perceptions of water; (2) life cycle assessment and water footprint analysis; (3) economic considerations; and (4) regulations and policy considerations. Specialty crop producers can either adapt to changes gradually, in a way that has the most benefit to them and their operations, or be forced to change by either regulations or environmental factors outside of their control. Specialty crop producers need the best information available to make informed decisions regarding management of their operation. Although this review focuses on specialty crop production in containers, much of what is discussed in this review is also directly applicable to agriculture in general and urban and suburban stormwater management.

\section{Consumer and Grower Perceptions}

Individuals typically make decisions that seem best to them, but these choices may or may not be based on logic or data. Understanding how people make decisions and the type of information that informs those decisions can have a profound impact on grower adoption of practices, profitability, and business survival. Many decisions regarding what crops to grow and how to grow them are influenced both by reality and perceptions. Economics, climate, weather, location, market conditions (previous, current, and predicted), and industry trends affect crop choice, management decisions, and production area devoted to a particular crop. While many of these factors influence how growers make decisions, 
they are not the only factors that impact why a grower chooses one option over another. Cultivar selection, irrigation decisions (ranging from type of irrigation method to scheduling), the level of automation, and various other production factors also influence grower choices. The basis for making many of these types of decisions are rooted in human psychology and economics. By increasing our understanding of why growers make decisions, we can help reduce or eliminate the barriers (either real or perceived) related to technology and adoption of practices that may be beneficial to the grower (lowering costs, raising outputs, decreasing environmental impact, etc.). Part of the solution is to provide decision makers (consumers, growers, and lawmakers) with quality information to help inform their decision process.

A major consideration in water use and recycling effectiveness centers around grower adoption of tools and techniques for water conservation. Existing and emerging technologies and practices can help achieve improvements in water quality and conservation. However, when faced with a complex decision on whether to engage in new practices or the adoption of new technologies, growers may be motivated differently to act or not act based on a variety of internal and external influences including their personal values and beliefs, the beliefs of those they trust, potential or current regulations, level of knowledge, and prior experience [12,13]. The difficulty is that humans, in general, tend to be reluctant to change behaviors unless they deem it advantageous over their current practice. The key to positively affecting water resources lies in the adoption of new technologies and practices designed to protect and preserve natural resources. Pro-environmental behaviors, such as growers adopting water-conserving practices and technologies, are defined as those behaviors adopted to reduce one's impact on the natural and built world [14].

Growers will move through an adoption process while considering whether they will engage with new practices or technologies. Initially, some growers may become aware of a practice or technology, which may lead to their seeking out additional information [15] such as how much it costs, how it will impact their current practices, and whether or not their peers believe it is a good innovation [16]. Once a grower has more information, they will decide to adopt or reject the innovation [15]. Growers who decide to adopt will implement the new practice, after which a decision is made whether or not to continue its use based on their personal experience [15]. During this process, extension professionals can provide growers with information and support to assist them in moving towards adoption, overcoming barriers to change by acknowledging concerns and offering new information.

It is important to understand grower perceptions and attitudes in order to encourage proactive engagement in pro-environmental practices, because behavior change is complex. Current research suggests cognitive indicators, contextual considerations, and multivariate influences focused on factors that relate to risk/gain, culture/demographics, values/beliefs, and specific knowledge all need to be considered in the decision-making process related to emergent technologies and best management practices [12,17-19]. Rogers [15] identified specific characteristics of innovations that can make implementation more attractive. Practices and technologies that are most likely to be adopted will: 1) have a clear advantage over what is currently being used; 2) will be compatible with the existing infrastructure (therefore some practices will be readily adopted by some and not by others); 3) will be simple to learn to use; and 4) will be easily tested to ensure they work [15]. Lamm, et al. [19] reported the opportunity to use new water treatment and conservation technologies on a trial basis could both positively and negatively influence nursery and greenhouse growers' eventual adoption, depending on the type of experience the grower had while using the conservation technology.

Through qualitative interviews of 20 U.S. nursery and greenhouse growers, Lamm et al. [12] found that stakeholders' adoption of water conservation technologies may be hindered by perceived cost and complexity. According to Lamm et al. [19], protecting "natural resources was the most frequently mentioned motivator for water conservation" and growers were found to care deeply about how they compare to their peers and how they are perceived by customers in terms of environmental stewardship. Dennis et al. [20] identified incompatibility of new practices as a primary barrier to change when studying sustainability within nursery and greenhouse operations. Similarly, Lamm et al. [12] 
reported that a lack of available space to house specific water conservation technologies and lack of compatibility between an operation's existing infrastructure and new technologies were barriers to adoption.

Following a quantitative multi-criteria decision analysis with nursery and greenhouse growers where cognitive factors as well as adoption characteristics were studied using structural education modeling and a series of linear and logistic regression data analysis, Warner et al. [18] reported that more than half of all growers who had implemented one of eight specific conservation technologies continued to use them, highlighting the educational importance of providing support for initial implementation and continued use. Extension and other professionals can increase the likelihood of adoption by showing growers how new technologies are compatible with their existing systems while emphasizing ease of implementation, financial benefits, and decreased production risk to the operation [21]. Additionally, professionals can encourage growers to adopt new technologies and practices by activating social norms among this audience [19].

Increased consumer demand for sustainably produced plants also plays a role in encouraging growers to engage in technologies and practices that protect water resources. Research has demonstrated that groups or segments of consumers prefer pro-environmental production practices, and this demand may be accompanied by a willingness to pay more for sustainably grown plant materials [22,23]. Consumers placed a higher relative importance on plant water use in the landscape compared to use in production and preferred fresh-water to recycled water or a blend of fresh-and recycled water [24]. Furthermore, consumers who accurately perceived they were in a drought situation exhibited different attitudes and behaviors compared to individuals who did not accurately perceive they were in a drought situation [25]. Pro-water conserving attitudes and behavior are more likely observed among individuals with greater plant purchases and who place a higher value on activities in a landscaped environment [26]. Consumer perceptions about the terminology of reused water influences their perceptions of safety. For example, subjects in an online survey perceived recycled water to be less risky compared to a cohort sample who saw identical questions with remediated water [27]. Yet, using a priming message (that the water was recycled from a production nursery compared to a residential area) reduced the perceived risk [28]. When growers understand the increased likelihood of selling their products at a higher price, they may be encouraged to engage as it represents a clear financial advantage to their current practices [15]. Lamm et al. [13] recommended ensuring that growers are aware of consumer demand for plants grown using techniques that protect water as a strategy to encourage adoption among nursery and greenhouse growers.

Armed with this consumer research, nursery and greenhouse producers can take a more proactive role in communicating their ecofriendly practices through business to consumer or business to business communications. This branding can include information on life cycle assessment (including carbon sequestration) and water footprint analysis. In addition, businesses can help to facilitate a shift toward more informed consumer choices when selecting plant materials by influencing public attitudes, creating social norms around choosing sustainably produced plant materials, and producing and communicating drought-tolerant plant material readily available to consumers, and therefore giving the consumer control over their choices [16]. To enhance market demand, extension professionals should also educate consumers on the environmental value of plants grown using more environmentally friendly practices [21].

Understanding the decision-making process for both growers and consumers can help improve adoption of environmentally and economically beneficial practices. It is important to understand the adoption process and provide stakeholders (both commercial and consumers) with quality information for making informed decisions. Ideally, new technologies will provide a clear advantage over existing practices, be compatible with existing infrastructure, simple to use, and easily tested to ensure proper functionality. Educating and providing growers with support for implementing new technologies as well as highlighting consumer demand for sustainably produced products can help increase adoption rates of alternative practices and technologies. 


\section{Life Cycle Assessment and Water Footprint Analysis}

The societal benefits of ornamental specialty crops are often not conveyed to consumers in an effective way. This is particularly true for life cycle assessment (LCA), carbon footprint (CF), and water footprint (WF) of ornamental specialty crops; this is an emerging field of study with oftentimes limited data. An LCA is a systematic process for determining the potential environmental impacts of interrelated input components and processes of a product or practice during its complete life cycle, from when it is created to when it is destroyed (cradle-to-grave) [29]. Potential impacts are categorized as either midpoint or endpoint impact potentials [30,31]. Midpoint impacts are based on measured values, which minimizes forecasting errors and generates predictable environmental impacts suitable for relative comparisons. Examples of midpoint impacts would be the global warming potential (kilograms of carbon dioxide or equivalent emitted), CF, and WF [32,33]. Endpoint analysis requires estimation of specific damages to human health or the environment (e.g., crop damage, skin cancer, cataracts, and immune system suppression) and is characterized by higher levels of uncertainty than midpoint impact potentials [32].

The CF and lifecycle impact of trees produced in pot-in-pot or field production systems were similar, however input materials such as plastics were a primary contributor in the pot-in-pot system while equipment use contributed the most in field production [34,35]. Labor was the primary contributor to shrub harvesting costs while equipment use was the greatest contributor to tree harvesting costs. This information is useful to nursery managers as they consider ways to increase efficiency and decrease emissions and costs. One benefit that is often overlooked for large shrubs and trees is the carbon sequestration that occurs during a plant's active growth in the landscape. The carbon sequestered in wood during a tree's life cycle is many times greater than greenhouse gas emissions during production $[36,37]$ and only one of several ecosystem services provided by landscape plants. Life cycle assessment of ornamental specialty crop production is a relatively new area, with limited information. Future research in this area would be beneficial to better understand how various factors (irrigation, species grown, container size, harvesting and shipping, etc.) impact the water and carbon footprints of a single plant (functional unit).

Water footprint [38], expressed in cubic meters of water per functional unit produced, is not a direct measure of water use or withdrawal from the ecosystem but is a term adjusted for water use or withdrawal, based on actual practices. Calculations based on water consumption instead of water withdrawal may be a more complete and accurate method of measuring WF for agriculture because approximately $40 \%$ of withdrawals typically flow to local streams and aquifers [39,40]. Most WF studies have focused on a global, country, or major river basin scales for specific field-grown crops such as wheat [41], with few focusing on smaller scale operations such as specialty crop producers.

Data inputs to WF calculations typically include withdrawal or consumption from surface and ground water sources required by a product using a correction factor for the availability and consumption of water in a global region on a monthly basis, defined as the water scarcity indicator (WSI) [42,43]. When considered on a monthly basis, there is more WSI stress during the summer months, the time that irrigation is used to augment available soil moisture. While WF encompasses water defined as blue, green, or gray water [44], the WSI considers the water requirements for healthy ecosystems in the region in defining available "blue" water as the volume of water that can be consumed without adverse ecological impacts.

Blue water is generally characterized as the consumptive use of surface and ground water flows. "Green" water is considered the direct precipitation that does not run off or recharge groundwater but is stored in the soil and evaporated from the surface or through the crop (evapotranspiration). The line between blue and green water is blurred in specialty crop operations, namely open-air container production systems with semi-permeable surfaces and catchments for rainfall and irrigation runoff, providing or supplementing irrigation water. If the system is closed or semi-closed (i.e., water does not leave the nursery property), the operation itself could be considered a complete watershed and all water could to be identified as blue water. "Gray" water is the volume of water needed to dilute a 
pollutant load to background levels or to meet existing ambient water quality standards, such that the contaminant becomes harmless to the aquatic ecosystem [44].

There are several common methods of calculating WF with adjustments for WSI including the Hoekstra et al. [38], Pfister et al. [45], and Boulay et al. [46] methods. The Pfister method is based on a water withdrawal-to-availability ratio. The Hoekstra and Boulay methods use a consumption-to-availability ratio. Average global WF, using the Hoekstra method, for tomatoes and fresh apples were reported as 214 and $822 \mathrm{~m}^{3} \cdot \mathrm{t}^{-1}$, respectively [44]. The propagation-to-gate WF using the Hoekstra method for three field-production systems for trees ranged from 0.09 to $0.64 \mathrm{~m}^{3}$ per tree and irrigation water accounted for $76 \%$ to $97 \%$ of the WF [34]. Irrigation water applied for modeled red maple, redbud, and blue spruce production systems in the Midwestern U.S., including liner production, was $0.623,0.693$ and $0.078 \mathrm{~m}^{3}$ per tree, respectively. These values were higher than the WFs adjusted by the WSI for the region. The model system for the blue spruce was characterized by minimal, individual-tree irrigation. For comparison, the redbud WF was lower using the Pfister $\left(0.356 \mathrm{~m}^{3}\right)$ and Boulay $\left(0.137 \mathrm{~m}^{3}\right)$ methods, which utilized different WSIs based on different models for global water availability and consumption. A new WF calculation method for weighting monthly consumptive water use based on a watershed's scarcity from a global context, Available Water Remaining (AWARE), has recently gained favor in the international community [47].

Production managers benefit from an understanding of applied water, consumptive use water and WF for their operation. Applied water can be used to assess irrigation efficiencies. Consumptive water use data help managers assess water management strategies. WF data allows the comparison of water use in terms of water availability in their area as well as in a global context. A more detailed analysis of these factors in case studies has been published [48].

Lifecycle assessment is an emerging field for documenting the impact of plant production and use on the environment. This information is useful to growing operations as they consider ways to increase efficiency and decrease emissions and costs. Consumers can also use this information to make more informed decisions regarding purchasing plants based on the environmental impact of plant production methodology. A large, often overlooked, benefit of large shrubs and trees is the mass of carbon sequestration that occurs during its growth. Carbon sequestered during growth is many times greater than carbon released during production. Additional ecosystem services provided by landscape plants include wildlife habitat, water remediation, and shading/cooling. WF analysis quantifies the relative abundance and availability of water and can help growers and consumers better understand the impact that water availability has on plant production. In general, if two operations use the same amount of water, one is located in area with high rainfall, and the other receives low rainfall, the low rainfall location will have a higher WF, since there is less water available in the "system". Research is needed to determine how growers can integrate CF and WF information to optimize production practices to enhance the environmental sustainability of their operation, while also enhancing their long-term economic viability. Additional information is also needed on the best methods to share this information with the general public to help them make informed decisions regarding plant purchases.

\section{Economic Considerations}

The adoption of advanced irrigation best management practices within the nursery and greenhouse industry ultimately involves a fundamental economic analysis of every recommended change relative to current standard irrigation practices in the industry. There are also social and societal implications including how growers are perceived by others, and the real or perceived barriers to adoption that exist for changing production practices. Changes in local, state, or federal regulation or weather can also impact a grower's bottom line either positively or negatively. Adoption of new practices within an industry can be rapid if the practices fit into current infrastructure and are financially beneficial, thus it is necessary for growers to understand economic dimensions prior to adoption. An economic engineering approach is generally used to estimate the initial capital investment, production costs, and product prices for both baseline and alternative nursery and greenhouse irrigation models. 
Partial budgeting is a tool that compares the negative effects (costs added) of applying a new treatment relative to a base or standard treatment to the positive effects (cost savings) associated with the new treatment relative to the base or standard treatment. Therefore, in terms of water management, it requires the consideration of the returns associated with treatments and changes in the structure of the production/irrigation costs. Aspects of costs and returns that do not change with the treatment, relative to the base are not considered in this portion of the analysis. Thus, the technique of partial budgeting examines only the effect of the proposed change in practice, assuming all other aspects of the green industry value chain remain unchanged. This is done by considering the physical changes associated with the alternatives being proposed and then determining the effects of these changes on the financial position of the business using total costs of production or irrigation as a proxy.

Specifically, water management project impacts should be evaluated by measuring four separate effects including: (1) added costs of production incurred by the use of alternative materials, cultural practices, irrigation treatments, or a combination of the three; (2) added income resulting from increased levels of production or price premiums associated with higher quality crops or both; (3) costs savings realized through more efficient management practices or reduced inputs; and (4) income that may be lost when substituting one crop for another in the production system. When the development phase of the proposed irrigation practices extends beyond two years, it is important to take into account the effect of delayed returns by using a net present value (capital budgeting) analysis to fully take into account the longer-term nature of any investment in capital equipment that may be necessary to implement some of the proposed changes in production or irrigation practices.

Irrigation control via sensor networks are an example of economic benefits leading to changes in practices. In a series of experiments with growers, sensor networks provided a number of benefits, depending upon how they were integrated with current practices. Several nursery operations reported significant water savings for multiple species of plants. Water savings alone were not adequate to encourage investment in sensor networks; growers changed practice only when there was a financial incentive from reduced production time, lower plant losses, or reduced chemical inputs. Changes in practice (i.e., sensor network for irrigation control) were often applied to additional areas under production after the technology was proven effective, accurate, and easy to use and maintain [49-51]. Reduction in labor requirements and pumping costs were appreciable for sensor network applications in containerized pot-in-pot production system [52]. Through a grower survey, Lichtenberg et al. [53] determined growers were willing to pay for advanced irrigation systems because they believed these systems would increase profits or decrease costs over current practice. When sensor networks were applied to strawberry production, the observed benefit was large compared to current practice [54], but Belaynah and Lea-Cox [54] suggested further study was warranted, particularly for evaluating sensor network benefits in different climates. Growers were found to be more likely to adopt practices that provided a competitive or financial advantage to their operation [55].

The sensitivity of the results to various production input prices, wage rates, and operational conditions can be investigated by altering values of the selected variables one at a time, from the baseline values. Changes in the selected variables will be expressed by variation from $+100 \%$ to $-50 \%$. The projected variables to be included in the sensitivity analysis include total investment costs, total labor costs, product prices and the useful life of equipment used in irrigation activities. Growers are more likely to implement technologies or practices that are able to save water, are economically beneficial, and have a positive environmental impact (in terms of ecosystem services provided) $[12,18]$.

Economic considerations are important for most major decisions in greenhouse and nursery crop production. Adoption of irrigation best management practices can be rapid if those changes fit into current production practices and provide an economic benefit. It is important for research and extension to evaluate installation and maintenance costs, return on investment, and other economic considerations for new and emerging technologies to provide useful information to inform adoption. Extension programs should explain economic information when working with growers who are 
thinking about changing practices to enhance production efficiency. It is also critical to use information generated by sociological studies so data are presented in a manner that encourages adoption.

\section{Regulations and Policy Considerations}

Growers may be influenced to change practice by personal convictions or outside influences (e.g., consumer perceptions, research-based information). Regulations may also require growers to change practices, as governments seek to conserve and protect water resources, either by limiting withdrawals from certain sources or by managing production return flows and stormwater. As the population increases, this could lead to more conflicts over surface and ground water resources, particularly in arid regions in the Southwest and Western USA, as well as other areas of the world where water is limited [55-57]. Recently, there have been conflicts at the state and local level over surface water [57-60]. These conflicts will likely lead to new laws and regulations for water allocation and use at the federal, state and local level. These laws may differentially impact cities, industry, and agriculture, depending on how regulations are enacted. It is possible that there will be changes to the way that water is allocated, compared with historical norms. There may also be population shifts away from more arid regions and towards areas with higher annual rainfall if water shortages persist and alternative fresh-water sources are not adequate to meet population demands. It is clear that any of these scenarios will impact specialty crop production in the US, and growers should be encouraged to adopt practices that save water and other resources (agrichemicals, substrates, petroleum, etc.) when feasible.

Waterways in California, Florida, and the Chesapeake Bay watershed are regulated for specific chemical, physical, and biological contaminants. These regulated waterways represent only a small portion of the total number of impaired waterways that can be regulated under the U.S. Clean Water Act $[61,62]$. As the U.S. Environmental Protection Agency and state regulatory agencies continue to identify impaired waterways, establish a total maximum daily load for each contaminant of concern, and develop planning tools to restore water quality, new and additional regulations are likely to be enacted across the country. It is important for growers and researchers to remain engaged at all levels of government (local, state, and federal). Growers need to stay informed about the proposed changes and understand how those changes might impact their operational practices. Regulators also need to be informed about the proactive practices growers have implemented to protect the environment and conserve water resources, so that the consequences of proposed regulations to growers are understood in the context of the changes growers have already implemented, and to better understand the implications of proposed regulatory changes have on grower's profitability and the environment. Implementing new technologies and practices may also help growers reduce water needs, both by changing practices to enhance operational water use efficiency and by developing the infrastructure capacity to treat and reuse water [51,63].

The impact of climate change adds another layer of uncertainty with regard to water supply and demand. Climate change is predicted to impact rainfall, temperatures, and other weather patterns, increasing precipitation in some areas, with others becoming more arid $[64,65]$. Changes in seasonal weather patterns are also expected to impact the supply of supplemental irrigation during the growing season [66]. Growers may try to alleviate these changes through a combination of factors including drilling more wells, storing more surface water, increasing irrigation efficiency, and changing the mix of plants they grow [55]. Higher uncertainty regarding water availability should encourage growers to reduce water use, increase on-site storage, recapture or reuse water from their growing areas, or a combination of some or all of these practices [67-69].

Growers may also be able to use alternative water sources to meet their irrigation demand. One possibility is reclaimed water (treated municipal wastewater). Reclaimed water can be high in salts, particularly sodium chloride, and heavy metals, which may negatively impact plant growth [70,71]. Extensive infrastructure investment is also required to pipe water from the water treatment plants to where it can be used by growers [72,73]. Guaranteed use of a minimum water volume by growers 
and other potential users must be met to make installation of the infrastructure worthwhile [70,74]. Another concern with reclaimed water is that it is produced continually, while irrigation demands in specialty crop and agricultural production are seasonal, and constantly varying. Desalination systems are an alternative water source for those operations geographically proximate to the coast, or in areas with saltwater intruded aquifers. Desalination systems are complex, expensive, require a brine disposal plan, and are typically not feasible except for large operations and municipalities that can absorb the large initial infrastructure investment cost and ongoing operating expenses [75,76]. It is likely in the future that new technologies will be developed that help to reduce the cost of desalination, making the systems available to larger specialty crop growers that require high quality water for their operation [77].

Growers may face future legal restrictions on their water use from a number of different sources. Impaired waterway cleanup at the State and Federal level may require monitoring of production return flows that leave the property or installation of water treatment systems to reduce specialty crop impacts on waterways. There may also be restrictions on the quality (e.g., treated wastewater, surface water vs. well water) or quantity of water that is allowed to be withdrawn. Predicted changes in climate and weather patterns may also impact water availability and regulations if water becomes seasonally or chronically reduced. Growers should continue to work to ensure they have adequate protections in place well ahead of any mandated changes. It is always recommended that growers document changes in practice, particularly when those changes lead to reduced water usage or reductions in agrichemical application or runoff.

\section{Conclusions}

Ornamental horticulture accounts for $4.4 \%$ of all agricultural revenue in the United States, and $8.8 \%$ of all crop revenue [78], which represents a major portion of U.S. agricultural production. Even though ornamental production represents a relatively large amount of crop production, there are major knowledge gaps in terms of social, economic, environmental, and policy implications of practices and identifying beneficial ways to change practice. Making important decisions is often difficult. Positively influencing decision-making can be even more difficult. For growers and consumers, decisions may be influenced by knowledge, lack of knowledge, perceptions of technologies and practices, social norms, space availability, weather, regulations, and labor markets. It is important to understand that adoption of new technologies is a process where early adopters, who are often opinion leaders, are willing to adopt a new practice into their existing infrastructure. The success or failure of this endeavor is dependent on a number of factors including: how the new practice fits into their existing practices; trialability, or the ability to try a new practice at a small scale; and economics, or the ability of a new practice to either save money or make money. Producers should adapt marketing practices to influence consumer perceptions of the sustainability of nursery and greenhouse crop production. Growers, wholesalers, and retailers will become more profitable and sustain business longer if they can incorporate an understanding of how consumers interact with and process information, and determine what information is important to consumers so that it can be incorporated into marketing plans. Another driver of grower and consumer choice may be life cycle analysis that provides cradle to grave understanding of water use and carbon emissions for horticultural production. Green industry professionals should leverage the environmental benefits of the crops they produce, particularly longer-lived shrubs and trees that sequester a significant amount of carbon over many years they are in the landscape. Too often, the ecosystem services related to mitigation of soil erosion, habitat restoration, and pollution reduction are either ignored entirely, marginally addressed, or undervalued. The more adept industry professionals become at telling why plants are valuable and how they benefit human health and the environment, the more marketable plants become, and their continued production justified, regardless of reduced water resource availability. Technologies and practices that show a net positive economic impact are more likely to be considered and implemented by growers. For growers to remain competitive, meet the demands of the customer, and abide by governing local, state and 
federal laws, researchers, extension agents, and policy makers need to work together to see changes as they are coming and help growers respond accordingly.

Author Contributions: All authors, J.C.M., B.B., C.R.H., D.L.I., A.J.L., L.A.W., and S.A.W., contributed to the writing, reviewing, and editing of this paper.

Funding: This material is based upon work that is supported by the National Institute of Food and Agriculture, U.S. Department of Agriculture, under award number 2014-51181-22372 and project numbers 1700536, 1700539. Technical contribution no. 6800 of the Clemson University Experiment Station.

Conflicts of Interest: The authors declare no conflict of interest.

\section{References}

1. De Châtel, F. Perceptions of Water in the Middle East: The Role of Religion, Politics and Technology in Concealing the Growing Water Scarcity. In Water Resources in the Middle East: Israel-Palestinian Water Issues_From Conflict to Cooperation; Shuval, H., Dweik, H., Eds.; Springer: Berlin/Heidelberg, Germany, 2007; pp. 53-60. [CrossRef]

2. Attari, S.Z. Perceptions of water use. Proc. Natl. Acad. Sci. USA 2014, 111, 5129-5134. [CrossRef] [PubMed]

3. Falkenmark, M.; Rockström, J. The New Blue and Green Water Paradigm: Breaking New Ground for Water Resources Planning and Management. J. Water Resour. Plan. Manag. 2006, 132, 129-132. [CrossRef]

4. Aguilera-Klink, F.; Pérez-Moriana, E.; Sánchez-García, J. The social construction of scarcity. The case of water in Tenerife (Canary Islands). Ecol. Econ. 2000, 34, 233-245. [CrossRef]

5. Petra, D. Vulnerability to the impact of climate change on renewable groundwater resources: A global-scale assessment. Environ. Res. Lett. 2009, 4, 035006.

6. Wada, Y.; van Beek, L.P.H.; van Kempen, C.M.; Reckman, J.W.T.M.; Vasak, S.; Bierkens, M.F.P. Global depletion of groundwater resources. Geophys. Res. Lett. 2010, 37. [CrossRef]

7. Jenkins, M.W.; Lund, J.R.; Howitt, R.E. Using Economic Loss Functions to Value urban water scarcity in California. J. Am. Water Works Assoc. 2003, 95, 58-70. [CrossRef]

8. Salmond, J.A.; Tadaki, M.; Vardoulakis, S.; Arbuthnott, K.; Coutts, A.; Demuzere, M.; Dirks, K.N.; Heaviside, C.; Lim, S.; Macintyre, H.; et al. Health and climate related ecosystem services provided by street trees in the urban environment. Environ. Health 2016, 15 (Suppl. 1), S36. [CrossRef]

9. Bringslimark, T.; Hartig, T.; Patil, G.G. Psychological Benefits of Indoor Plants in Workplaces: Putting Experimental Results into Context. HortScience 2007, 42, 581-587. [CrossRef]

10. Yang, F.; Bao, Z.Y.; Zhu, Z.J. An assessment of psychological noise reduction by landscape plants. Int. J. Environ. Res. Public Health 2011, 8, 1032-1048. [CrossRef]

11. Gidlöf-Gunnarsson, A.; Öhrström, E. Attractive "quiet" courtyards: A potential modifier of urban residents' responses to road traffic noise? Int. J. Environ. Res. Public Health 2010, 7, 3359-3375. [CrossRef]

12. Lamm, A.J.; Warner, L.A.; Martin, E.T.; White, S.A.; Fisher, P. Enhancing extension programs by discussing water conservation technology adoption with growers. J. Agric. Educ. 2017, 58, 251-266. [CrossRef]

13. Lamm, A.J.; Warner, L.A.; Taylor, M.R.; Martin, E.T.; White, S.A.; Fisher, P. Diffusing Water Conservation and Treatment Technologies to Nursery and Greenhouse Growers. J. Int. Agric. Ext. Educ. 2017, 24, 105-119. [CrossRef]

14. Kollmus, A.; Agyeman, J. Mind the gap: Why do people act environmentally and what are the barriers to pro-environmental behavior? Environ. Educ. Res. 2002, 8, 239-260. [CrossRef]

15. Rogers, E.M. Diffusion of Innovations, 5th ed.; Free Press: New York, NY, USA, 2003.

16. Ajzen, I. The theory of planned behavior. Organ. Behav. Hum. Decis. Process. 1991, 50, 179-211. [CrossRef]

17. Lamm, A.J.; Warner, L.A.; Lundy, L.K.; Bommidi, J.S.; Beattie, P.N. Informing water-saving communication in the United States using the situational theory of problem solving. Landsc. Urban Plan. 2018, 180, 217-222. [CrossRef]

18. Warner, L.A.; Lamm, A.J.; Beattie, P.; White, S.A.; Fisher, P.R. Identifying Opportunities to Promote Water Conservation Practices among Nursery and Greenhouse Growers. HortScience 2018, 53, 958-962. [CrossRef]

19. Lamm, A.; Warner, L.; Taylor, M.; Martin, E.; White, S.; Fisher, P. Diffusing water conservation and treatment technologies to nursery and greenhouse growers. J. Intl. Agr. Ext. Educ. 2017, 24, 105-119. [CrossRef] 
20. Dennis, J.; Lopez, R.; Behe, B.; Hall, C.; Yue, C.; Campbell, B. Sustainable production practices adopted by greenhouse and nursery plant growers. HortScience 2010, 45, 1232-1237. [CrossRef]

21. Hall, T.J.; Dennis, J.H.; Lopez, R.G.; Marshall, M.I. Factors affecting growers' willingness to adopt sustainable floriculture practices. HortScience 2009, 44, 1346-1351. [CrossRef]

22. Behe, B.K.; Campbell, B.L.; Hall, C.R.; Khachatryan, H.; Dennis, J.H.; Yue, C. Consumer preferences for local and sustainable plant production characteristics. HortScience 2012, 48, 200-208. [CrossRef]

23. Khachatryan, H.; Campbell, B.; Hall, C.; Behe, B.; Yue, C.; Dennis, J. The effects of individual environmental concerns on willingness to pay for sustainable plant attributes. HortScience 2014, 49, 69-75. [CrossRef]

24. Knuth, M.; Behe, B.K.; Hall, C.R.; Huddleston, P.T.; Fernandez, R.T. Consumer Perceptions, Attitudes, and Purchase Behavior with Landscape Plants during Real and Perceived Drought Periods. HortScience 2018, 53, 49-54. [CrossRef]

25. Knuth, M.; Behe, B.K.; Hall, C.R.; Huddleston, P.; Fernandez, R.T. Consumer Perceptions of Landscape Plant Production Water Sources and Uses in the Landscape during Perceived and Real Drought. HortTechnology 2018, 28, 85-93. [CrossRef]

26. Behe, B.K.; Knuth, M.; Hall, C.R.; Huddleston, P.T.; Fernandez, R.T. Consumer Involvement with and Expertise in Water Conservation and Plants Affect Landscape Plant Purchases, Importance, and Enjoyment. HortScience 2018, 53, 1164-1171. [CrossRef]

27. McClaran, N.; Behe, B.K.; Huddleston, P.T.; Fernandez, R.T. Removing the yuck out of recycled water: The effect of water source and name. J. Risk Manag. 2019. in review.

28. McClaran, N.; Behe, B.K.; Huddleston, P. Ignorance is not use or bliss: The case for recycled water. HortScience. in preparation.

29. Baumann, H.; Tillman, A.-M. The Hitch Hiker's Guide to LCA: An Orientation in Life Cycle Assessment Methodology and Application; Studentlitteratur: Lund, Sweden, 2004; p. 543.

30. Bare, J.C.; Norris, G.A.; Pennington, D.W.; McKone, T. TRACI-The tool for the reduction and assessment of chemical and other environmental impacts. J. Ind. Ecol. 2003, 6, 49-78. [CrossRef]

31. U.S. Environmental Protection Agency. Life Cycle Assessment: Principles and Practices; EPA/600/R-06/060; U.S. Environmental Protection Agency: Wasthington, DC, USA, 2006; p. 80.

32. Laurent, A.; Olsen, S.I.; Hauschild, M.Z. Limitations of Carbon Footprint as Indicator of Environmental Sustainability. Environ. Sci. Technol. 2012, 46, 4100-4108. [CrossRef]

33. Page, G.; Ridoutt, B.; Bellotti, B. Carbon and water footprint tradeoffs in fresh tomato production. J. Clean. Prod. 2012, 32, 219-226. [CrossRef]

34. Ingram, D.L.; Hall, C.R. Life Cycle Assessment used to determine potential midpoint environment impact factors and water footprint of field-grown tree production inputs and processes. J. Am. Soc. Hortic. Sci. 2015, 140, 102-107. [CrossRef]

35. Ingram, D.L.; Hall, C.R.; Knight, J. Carbon Footprint and Variable Costs of Production Components for a Container-grown Evergreen Shrub Using Life Cycle Assessment: An East Coast U.S. Model. HortScience 2016, 51, 989-994. [CrossRef]

36. Ingram, D.L. Life cycle assessment of a field-grown red maple tree to estimate its carbon footprint components. Int. J. Life Cycle Assess. 2012, 17, 453-462. [CrossRef]

37. Ingram, D.L.; Hall, C.R. Carbon Footprint and Related Production Costs of System Components of a Field-Grown Cercis canadensis L. 'Forest Pansy' Using Life Cycle Assessment. J. Environ. Hortic. 2013, 31, 169-176. [CrossRef]

38. Hoekstra, A.Y.; Mekonnen, M.M.; Chapagain, A.K.; Mathews, R.E.; Richter, B.D. Global Monthly Water Scarcity: Blue Water Footprints versus Blue Water Availability. PLoS ONE 2012, 7, e32688. [CrossRef] [PubMed]

39. Perry, C. Efficient irrigation, inefficienct communication; flawed recommendations. Irrig. Drain. 2007, 56, 367-378. [CrossRef]

40. Shiklomanov, I.A. Appraisal and assessment of world water resources. Water Int. 2000, 25, 11-32. [CrossRef]

41. Mekonnen, M.M.; Hoekstra, A.Y. A global and high-resolution assessment of the green, blue and gray water footprint of wheat. Hydrol. Earth Syst. Sci. 2010, 14, 1259-1276. [CrossRef]

42. Alcamo, J.; Henrichs, T.; Rosch. World Water in 2025: Global Modeling and Scenario Analysis for the World Commission on Water for the 21st Century; Kassel World Water Series, Report No. 2. Kassel, Germany, 2000. 
43. Smakthin, V.; Revenga, C.; Doll, P. Taking into account environmental water requirements in global-scale water resources assessments. In Comprehensive Assessment Water Resource Report 2; International Water Management Institute: Battaramulla, Sri Lanka, 2004; p. 24.

44. Mekonnen, M.M.; Hoekstra, A.Y. The green, blue and gray water footprint of crops and derived crop products. Hydrol. Earth Syst. Sci. 2010, 15, 1577-1600. [CrossRef]

45. Pfister, S.; Koehler, A.; Hellweg, S. Assessing the environmental impacts of freshwater consumption in LCA. Environ. Sci. Technol. 2009, 43, 4098-4104. [CrossRef]

46. Boulay, A.-M.; Bulle, C.; Bayart, J.-B.; Deschenes, L.; Margni, M. Regional characterization of freshwater use in LCA: Modeling direct impacts on human health. Environ. Sci. Technol. 2011, 45, 8948-8957. [CrossRef]

47. Boulay, A.-M.; Bare, J.; Benini, L.; Berger, M.; Lathuillière, M.J.; Manzardo, A.; Margni, M.; Motoshita, M.; Núñez, M.; Pastor, A.V.; et al. The WULCA consensus characterization model for water scarcity footprints: Assessing impacts of water consumption based on available water remaining (AWARE). Int. J. Life Cycle Assess. 2018, 23, 368-378. [CrossRef]

48. Knight, J.; Ingram, D.L.; Hall, C.R. Workshop: Understanding Irrigation Water Applied, Consumptive Water Use, and Water Footprint Using Case Studies for Container Nursery Production and Greenhouse Crops. HortTechnology 2019, 1, 1-7. [CrossRef]

49. Chappell, M.; Dove, S.K.; van Iersel, M.W.; Thomas, P.A.; Ruter, J. Implementation of Wireless Sensor Networks for Irrigation Control in Three Container Nurseries. HortTechnology 2013, 23, 747-753. [CrossRef]

50. Saavoss, M.; Majsztrik, J.; Belayneh, B.; Lea-Cox, J.; Lichtenberg, E. Yield, quality and profitability of sensor-controlled irrigation: A case study of snapdragon (Antirrhinum majus L.) production. Irrig. Sci. 2016, 34, 409-420. [CrossRef]

51. Lea-Cox, J.D.; Bauerle, W.L.; van Iersel, M.W.; Kantor, G.F.; Bauerle, T.L.; Lichtenberg, E.; King, D.M.; Crawford, L. Advancing Wireless Sensor Networks for Irrigation Management of Ornamental Crops: An Overview. HortTechnology 2013, 23, 717-724. [CrossRef]

52. Belayneh, B.E.; Lea-Cox, J.D.; Lichtenberg, E. Costs and Benefits of Implementing Sensor-controlled Irrigation in a Commercial Pot-in-Pot Container Nursery. HortTechnology 2013, 23, 760-769. [CrossRef]

53. Lichtenberg, E.; Majsztrik, J.; Saavoss, M. Grower demand for sensor-controlled irrigation. Water Resour. Res. 2015, 51, 341-358. [CrossRef]

54. Belayneh, B.; Lea-Cox, J. Using sensor networks to maximize irrigation water use efficiency in strawberry production. In Proceedings of the VIII International Symposium on Irrigation of Horticultural Crops 1150, Lleida, Spain, 8-11 June 2015; pp. 399-406.

55. White, S.A.; James, S.; Owen, J.; Majsztrik, J.C.; Oki, L.R.; Fisher, P.R.; Hall, C.R.; Lea-Cox, J.D.; Fernandez, R.T. Greenhouse and Nursery Water Management Characterization and Research Priorities in the USA. Water 2019. in review.

56. Majsztrik, J.C.; Ristvey, A.G.; Lea-Cox, J.D. Water and nutrient management in the production of container-grown ornamentals. Hortic. Rev. 2011, 38, 253-297.

57. Wolf, A.T. Criteria for equitable allocations: The heart of international water conflict. Nat. Resour. Forum 1999, 23, 3-30. [CrossRef]

58. Water Webster. Florida, Alabama, and Georgia Water Sharing. Available online: http://www.waterwebster. org/FloridaAlabamaGeorgia.htm (accessed on 17 October 2015).

59. Blue, C.O. North vs. South-Carolina States Settle Water Dispute Without Supreme Court. Available online: http://www.circleofblue.org/waternews/2011/world/north-vs-south\%E2\%80\%94carolina-statessettle-water-dispute-without-supreme-court/ (accessed on 22 October 2015).

60. Scholz, J.T.; Stiftel, B. Adaptive Governance and Water Conflict: New Institutions for Collaborative Planning; Routledge: Washington, DC, USA, 2010.

61. Majsztrik, J.; Lea-Cox, J.D. Water quality regulations in the Chesapeake Bay: Working to more precisely estimate nutrient loading rates and incentivize best management practices in the nursery and greenhouse industry. HortScience 2013, 48, 1097-1102. [CrossRef]

62. U.S. Environmental Protection Agency. Impaired Waters and TMDL's. Available online: https://www.epa. gov/tmdl (accessed on 5 September 2019).

63. Majsztrik, J.C.; Fernandez, R.T.; Fisher, P.R.; Hitchcock, D.R.; Lea-Cox, J.; Owen, J.S.; Oki, L.R.; White, S.A. Water Use and Treatment in Container-Grown Specialty Crop Production: A Review. Water Air Soil Pollut. 2017, 228, 151. [CrossRef] [PubMed] 
64. International Panel on Climate Change. Climate Change 2014: Synthesis Report. Contribution of Working Groups I, II and III to the Fifth Assessment Report of the Intergovernmental Panel on Climate Change; Core Writing Team, Pachauri, R.K., Meyer, L.A., Eds.; IPCC: Geneva, Switzerland, 2014; p. 151.

65. Walther, G.-R.; Post, E.; Convey, P.; Menzel, A.; Parmesan, C.; Beebee, T.J.C.; Fromentin, J.-M.; Hoegh-Guldberg, O.; Bairlein, F. Ecological responses to recent climate change. Nature 2002, 416, 389-395. [CrossRef] [PubMed]

66. Howden, S.M.; Soussana, J.-F.; Tubiello, F.N.; Chhetri, N.; Dunlop, M.; Meinke, H. Adapting agriculture to climate change. Proc. Natl. Acad. Sci. USA 2007, 104, 19691-19696. [CrossRef] [PubMed]

67. Bilderback, T.; Boyer, C.; Chappell, M.; Fain, G.; Fare, D.; Gilliam, C.; Jackson, B.; Lea-Cox, J.; LeBude, A.; Niemiera, A.; et al. Best Management Practices: Guide for Producing Nursery Crops, 3rd ed.; Southern Nursery Association: Atlanta, GA, USA, 2013; Available online: http://contents.sna.org/bmpv30.html (accessed on 2 November 2015).

68. Beeson, R.C., Jr.; Arnold, M.A.; Bilderback, T.E.; Bolusky, B.; Chandler, S.; Gramling, H.M.; Lea-Cox, J.D.; Harris, J.R.; Klinger, P.J.; Mathers, H.M.; et al. Strategic vision of container nursery irrigation in the next ten years. J. Environ. Hortic. 2004, 22, 113-115.

69. White, S.A. Wetland Technologies for Nursery and Greenhouse Compliance with Nutrient Regulations. HortScience 2013, 48, 1103-1108. [CrossRef]

70. Metcalf and Eddy, Inc.; Asano, T.; Burton, F.L.; Leverenz, H.; Tsuchihashi, R.; Tchobanoglous, G. Water Reuse; McGraw-Hill Professional Publishing: New York, NY, USA, 2007.

71. Chen, W.; Lu, S.; Jiao, W.; Wang, M.; Chang, A.C. Reclaimed water: A safe irrigation water source? Environ. Dev. 2013, 8, 74-83. [CrossRef]

72. Hering, J.G.; Waite, T.D.; Luthy, R.G.; Drewes, J.E.; Sedlak, D.L. A Changing Framework for Urban Water Systems. Environ. Sci. Technol. 2013, 47, 10721-10726. [CrossRef]

73. Bixio, D.; Thoeye, C.; Wintgens, T.; Ravazzini, A.; Miska, V.; Muston, M.; Chikurel, H.; Aharoni, A.; Joksimovic, D.; Melin, T. Water reclamation and reuse: Implementation and management issues. Desalination 2008, 218, 13-23. [CrossRef]

74. Hernández, F.; Urkiaga, A.; De las Fuentes, L.; Bis, B.; Chiru, E.; Balazs, B.; Wintgens, T. Feasibility studies for water reuse projects: An economical approach. Desalination 2006, 187, 253-261. [CrossRef]

75. Karagiannis, I.C.; Soldatos, P.G. Water desalination cost literature: Review and assessment. Desalination 2008, 223, 448-456. [CrossRef]

76. Younos, T. The Economics of Desalination. J. Contemp. Water Res. Educ. 2005, 132, 39-45. [CrossRef]

77. Al-Karaghouli, A.; Kazmerski, L.L. Energy consumption and water production cost of conventional and renewable-energy-powered desalination processes. Renew. Sustain. Energy Rev. 2013, 24, 343-356. [CrossRef]

78. U.S. Department of Agriculture. 2017 Census of Agriculture; AC-17-A-51; National Agricultrual Statistics Service, 2019.

(C) 2019 by the authors. Licensee MDPI, Basel, Switzerland. This article is an open access article distributed under the terms and conditions of the Creative Commons Attribution (CC BY) license (http://creativecommons.org/licenses/by/4.0/). 